\title{
Climate Change, Growth Determinants and Tourism Industry: Time Series Analysis from Malaysia
}

\author{
Kittisak Jermsittiparsert \\ \{kittisak.j@chula.ac.th\} \\ Chulalongkorn University, Thailand
}

\begin{abstract}
The purpose of this study is to examine the factor of climate change and its influence on tourism in Malaysia. For climate change, key indicators are level of temperature, renewable energy consumption, rain fall, disaster risk reduction score, and droughts, flood, and extreme temperature as percentage of overall population. In addition, population growth rate and GDP per capita growth rate are also added in the models. For tourism industry two indicators under the title of tourism expenditure and international tourism receipt are examined. Time duration of the study consist of 1970 to 2017 with annual observations. Descriptive, correlation and regression analyses techniques are applied to examine the effect of growth factors and climate change on tourism industry. It is found that factors like temperature level, rain fall are playing their significant determinants of tourism dimensions. These findings are providing a significant guideline to various policy makers, country officials and those who are responsible to deal with increase issues of climate change in Malaysia. Additionally, theoretical and practical significance of the study can be viewed in a way that it has added reasonable empirical contribution in existing literature. However, study is limited towards the consideration of specific indicators under the title of climate change. Future research can be conducted while adding more factors of climate change in targeted regions.
\end{abstract}

Keywords: Climate Change, Tourism Receipt, Growth, GDP per Capita, Malaysia.

\section{Introduction and Background of the Study}

In the world economy, tourism industry is playing its vital for the economic prosperity and financial wellbeing. This sector is known as significant indicator to get significant amount of foreign exchange, creation of employment and other economic diversification as well [1], [2]. Various other sectors in the economy like agriculture, fishing, and services are directly and indirectly associated to tourism industry [3], [4]. Various economies in the world map are depending on the tourism for economic growth and increasing standard of living in the local market. The significance of tourism industry has motivated various researchers to put the light to determine which factors are playing their meaningful role. Additionally, relative prices, stability in the country, social, economic and other interaction in the economy are heavily depending upon tourism industry [5], [6]. However, in recent years, climate change is known as major factor, affecting the demand of tourism in the world economy [7]. Various regions are linked to their coastal locations have to deal with direct influence from the change in natural climate. The increasing trend of climate change is reflected in the form of flooding in various areas, increasing temperature, lowering the sea level, and other natural \& 
environmental outcomes [8]. Additionally, world is now facing a significant issue of extreme weather conditions which results in droughts in various areas, unexpected cyclones and other calamities [9]. It is observed that factor of climate change is impacting the tourism industry and intercontinental cultural trends. Meanwhile, it is affecting the water available and increasing certain health related disease, which in return lowers the tourism for many nations. This study has examined the effect of climate factors on tourism industry in the region of Malaysia. Graph below provides a comprehensive view of overall tourism receipt in Malaysia over last 48 years. It is observed that from 2000 to onward, there is a significant increase in tourism receipt and maximum value is achieved during 2008 to 2014. However, after 2014, slight decline is experienced due to various factors in the economy.

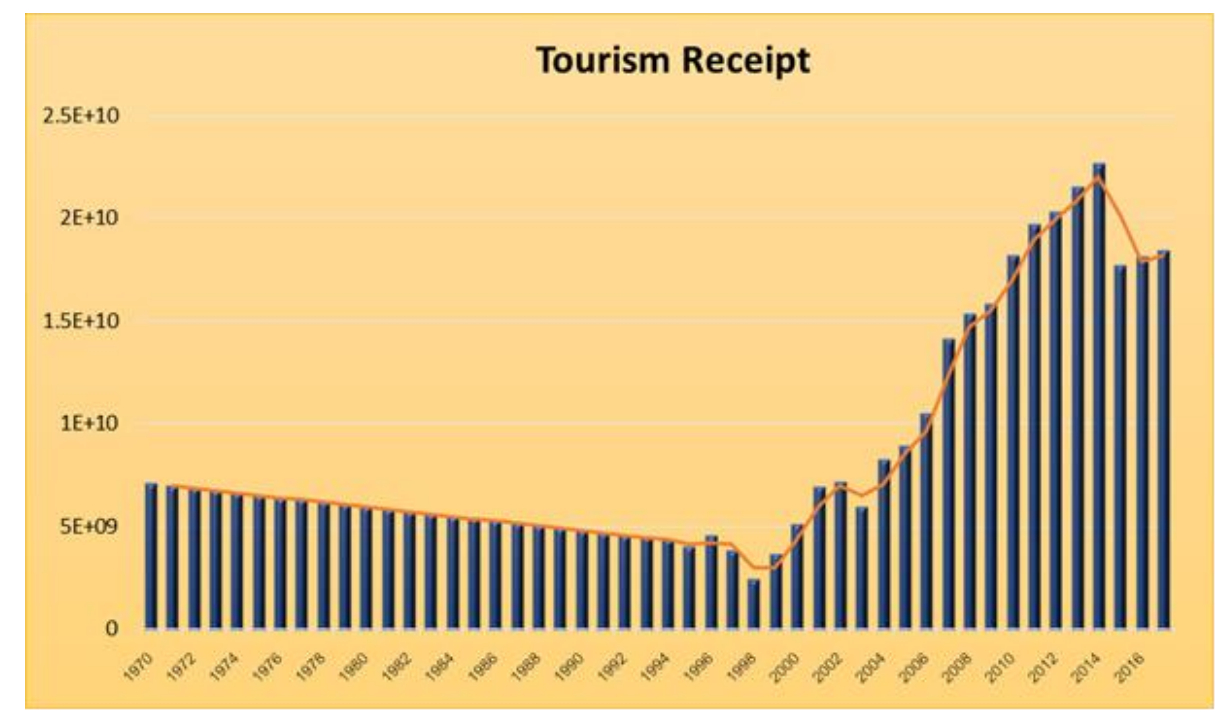

Fig. 1. Tourism Receipt in Malaysia 1970-2017 (World Bank Group 2018).

To the best of researcher's knowledge this study is among the significant contributions in ASEAN region to explore the impact of climate change on tourism. The rest of study is as follows. Section two describes literature context for climate change and tourism. Section three defines key variables with their measurement. Section four provides discussion over research methods. Section five explains findings of the study. Last section concludes the research with limitations and recommendations.

\section{Literature Context}

The factor of climate change is accepted as a critical factor, impacting the tourism and related decisions by the tourists. It is a common notion that with the passage of time, there is an increase in the level of temperature, both at sea and surface level, increasing rain patterns and other extreme weather outputs. It is common idea that those states which are dealing with the idea of tourism have to focus on the harmful or any effects of climate change. However, the pattern of literature studies reflects the fact that tourism and climate change have not been examined very well but in a separate way. In this regard, research work conducted by [10] can 
be viewed as significant contribution to study the idea of tourism and climate change in a spate way. While, some authors like [11] explain that climate change is an ongoing concept which impact the way like changing the managerial way of thinking and decision making. Meanwhile, they have pointed out the fact that significant determinant from climate change for tourism are radiation, sunshine, level of temperature, fog, humidity and wind as well. During the mid of 90s, authors like [12] have expressed their opinion for the climate change and its various impacts on tourism operations in the form of water supply, quality and cost etc. As per the research findings of 66 nations in the world economy to examine the national tourism with the metrological factors have found that climate change in the form of changing weather is the key determinant of tourism industry [13]. Authors like [14] explained their view that climate change is considered as among the most prevailing indicator affecting the global tourism industry. From the context of some developed economies, authors have also explored the idea of tourism and its determinants from overall change in climate. For example, [15] investigated the economy of Switzerland for the climate change and functioning of tourism industry. It is claimed that prevailing temperature is a significant determinant of snow in the country which in return affects the tourists from the world economy. Research study conducted by [16] pointed that factor of global warming have its devastating effect on the tourism industry.

In addition, research work conducted by [17], confirmed the fact that both factors of rain and temperature have their effects on the arrivals of tourism in Caribbean Islands for a period of 1989 to 2017. It is observed that climate change in targeted region is a significant determinant of tourism demand as it directly affects the decision for visiting these places. Some other authors have provided their significant contribution in existing literature to explore the relationship between tourism and climate change in developing economies [18], [19], [20], [21]. In this regard, research work by [22] have focused on the dynamic association between tourism development and environmental degradation in the region of Mauritius. Research study conducted by [23] discussed the fact that tourism destinations are very much sensitive on the planning and experience of visitors. Their study have concluded the fact that climate change in the form of more emission could have a long run and short run influence on tourism management and development. Additionally, it is recognized that previous experience about change in climate can directly affect the present decisions of the visitors.

\section{Description of Variables}

This study has considered the factor of climate change, population growth rate, GDP per capita growth rate and tourism as key indicators for their empirical relationship in the region of Malaysia. Details of all variables are presented below, with their operational measurement and data source.

\begin{tabular}{llll}
\hline Name of Variable & Official Measurement & Data Source & \\
\hline International tourism expense & $\%$ of total import & World & Development
\end{tabular}




\begin{tabular}{|c|c|c|}
\hline $\begin{array}{l}\text { International tourism receipt } \\
\text { current USD }\end{array}$ & Log of total receipt & $\begin{array}{l}\text { Indicator } \\
\text { World development Indicator }\end{array}$ \\
\hline Population Growth Rate & Annual growth rate & World development indicator \\
\hline $\begin{array}{ll}\text { Renewable } & \text { energy } \\
\text { consumption } & \end{array}$ & $\begin{array}{l}\text { Overall consumption in the } \\
\text { economy }\end{array}$ & World development indicator \\
\hline Temperature & Average temperature & World development indicator \\
\hline Rainfall & Average rainfall millimeter & World development indicator \\
\hline GDP per capita growth & Per capita growth of GDP & World development indicator \\
\hline $\begin{array}{l}\text { Disaster risk reduction } \\
\text { progress score }\end{array}$ & $1-5$ range, $5=$ best & World development indicator \\
\hline $\begin{array}{l}\text { Droughts, floods, extreme } \\
\text { temperature }\end{array}$ & $\%$ of population & World development indicator \\
\hline
\end{tabular}

\section{Research Methodology}

The main purpose of this study is to conduct an empirical investigation for the effect of climate change and growth factors on tourism industry of Malaysia. For this purpose, secondary data is collected during the time of 1970 to 2017 with annual observations. From the context of data analysis, descriptive techniques are applied at first, for analyzing the overall layout of data. In second step, correlation matrix is developed and VIF test is applied. In third step, regression technique is applied while considering three-time durations. At first analysis are conducted for the time period of 1970 to 1990, second is from 1991 to 2017 and third is based on 1970 to 2017. Followings are the regression equation of the study:

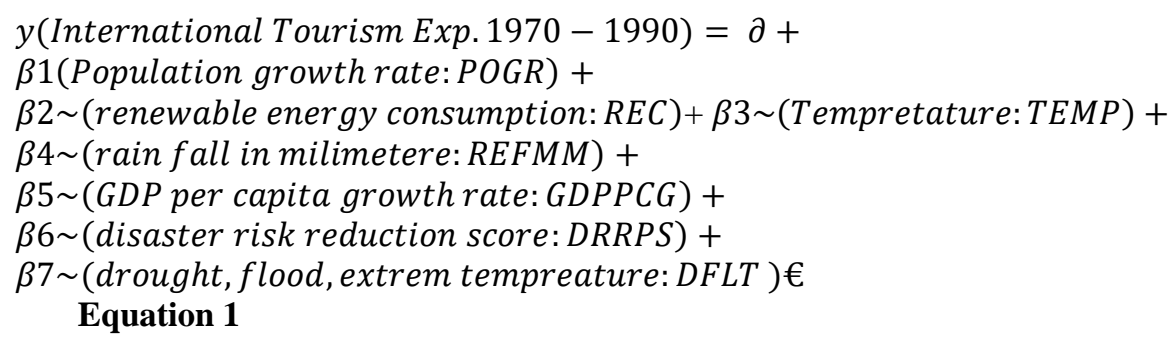

$y($ International Tourism receipt. $1970-1990)=\partial+$ $\beta 1($ Population growth rate: POGR $)+$ $\beta 2 \sim($ renewable energy consumption: $R E C)+\beta 3 \sim($ Tempretature:TEMP $)+$ 
$\beta 4 \sim($ rain fall in milimetere: $R E F M M)+$

$\beta 5 \sim(G D P$ per capita growth rate:GDPPCG) +

$\beta 6 \sim($ disaster risk reduction score: DRRPS $)+$

$\beta 7 \sim($ drought, flood, extrem tempreature: DFLT )€

Equation 3

$y($ International Tourism receipt. $1991-2017)=\partial+$

$\beta 1($ Population growth rate: POGR $)+$

$\beta 2 \sim($ renewable energy consumption: $R E C)+\beta 3 \sim($ Tempretature:TEMP $)+$

$\beta 4 \sim($ rain fall in milimetere: $R E F M M)+$

$\beta 5 \sim(G D P$ per capita growth rate: GDPPCG $)+$

$\beta 6 \sim($ disaster risk reduction score: DRRPS $)+$

$\beta 7 \sim($ drought, flood, extrem tempreature: DFLT )€

Equation 4

(International Tourism Exp.1970 - 2017) $=\partial+$

$\beta 1$ (Population growth rate: POGR) +

$\beta 2 \sim($ renewable ener gy consumption: $R E C)+\beta 3 \sim($ Tempretature: TEMP $)+$

$\beta 4 \sim($ rain fall in milimetere: $R E F M M)+$

$\beta 5 \sim(G D P$ per capita growth rate:GDPPCG $)+$

$\beta 6 \sim($ disaster risk reduction score: DRRPS) +

$\beta 7 \sim($ drought, flood, extrem tempreature: DFLT )€

Equation 5

$y($ International Tourism receipt. $1970-2017)=\partial+$

$\beta 1($ Population growth rate: POGR $)+$

$\beta 2 \sim($ renewable energy consumption: $R E C)+\beta 3 \sim($ Tempretature: TEMP $)+$

$\beta 4 \sim($ rain fall in milimetere: $R E F M M)+$

$\beta 5 \sim($ GDP per capita growth rate: GDPPCG $)+$

$\beta 6 \sim($ disaster risk reduction score: DRRPS) +

$\beta 7 \sim($ drought, flood, extrem tempreature: DFLT )€

Equation 6.

\section{Findings and Discussion}

Descriptive findings of the study are presented under table one, taking the title of core measures like mean, standard deviation, minimum, maximum, P1 to P99, skewness and kurtosis. For key explanatory variables, mean score for international tourism expense log value is 2.707 with the deviation from the mean is 1.75 . Maximum observation for the international tourism expense in the region of Malaysia over last 48 years is 5.781 with p99 of 2.781 and skewness of .265 as well. For log of tourism receipt, mean score is 9.861 and deviation of .244. For population growth rate under the title of climate change indicators as defined by World Bank group is 4.027 and deviation of .843. It means that since last 48 years, overall growth rate of population in the region of Malaysia is above four percent. For renewable energy consumption means score is 6.194 and for overall average annual temperature in the region is 25.542 degrees. For rain fall as measured through millimeter, 
mean score is 279.688 and deviation of 425.207 , considered as highest deviation in the data set. For GDP per capita growth a score of 3.438 as an annual average is observed over last 5 decades. While droughts, floods, extreme temperatures (\% of population) considers a score of 5.646 with the deviation of 2.89. The rating for Droughts, floods, extreme temperatures is based on five-point scale ranging from 1 as lowest and 5 as highest in over time.

Table 1. Descriptive Statistics

\begin{tabular}{llllllllll}
\hline Variables & & Mean & Min & Max & p1 & p99 & Skew. & Kurt. \\
& Obs & & Std.Dev. & & & & & & \\
\hline ITEXP & 48 & 2.707 & 1.715 & .007 & 5.781 & .007 & 5.781 & .265 & 2.019 \\
LGTR & 48 & 9.861 & .244 & 9.377 & 10.354 & 9.377 & 10.354 & .698 & 2.481 \\
POGR & 48 & 4.027 & .843 & 2.199 & 4.993 & 2.199 & 4.993 & -.716 & 2.051 \\
REC & 47 & 6.194 & 3.178 & .12 & 13.092 & .12 & 13.092 & .395 & 2.43 \\
TEMP & 48 & 25.542 & 1.473 & 23 & 28 & 23 & 28 & -.103 & 2.17 \\
REFMM & 48 & 279.688 & 42.207 & 212 & 349 & 212 & 349 & -.062 & 1.754 \\
GDPPCG & 48 & 3.942 & 3.443 & -9.656 & 9.114 & -9.656 & 9.114 & -1.734 & 6.986 \\
DRRPS & 35 & 3.438 & 1.303 & 1 & 5 & 1 & 5 & -.212 & 1.791 \\
DFLT & 38 & 5.646 & 2.899 & 1 & 10 & 1 & 10 & .151 & 1.712 \\
\hline
\end{tabular}

After descriptive analysis, correlation matrix pairwise are presented under table 2, covering all explanatory variables of climate change it is observed that correlation between population growth rate and renewable energy consumption is .293 , significant at 5 percent. Correlation between population growth and level of temperature is insignificant.

Table 2. Pairwise Correlations

\begin{tabular}{llllllll}
\hline VARIABLES & $(\mathbf{1})$ & $\mathbf{( 2 )}$ & $\mathbf{( 3 )}$ & $\mathbf{( 4 )}$ & $\mathbf{( 5 )}$ & $\mathbf{( 6 )}$ & $\mathbf{( 7 )}$ \\
\hline (1) POGR & 1.000 & & & & & & \\
(2) REC & $0.293^{* *}$ & 1.000 & & & & \\
& 0.046 & & & & & \\
(3) TEMP & 0.020 & -0.094 & 1.000 & & & \\
& 0.892 & 0.528 & & & & \\
(4) REFMM & -0.063 & -0.147 & 0.141 & 1.000 & & \\
& 0.672 & 0.326 & 0.340 & & & \\
(5) GDPPCG & 0.210 & 0.130 & -0.128 & -0.115 & 1.000 & & \\
& 0.152 & 0.385 & 0.385 & 0.436 & & & \\
(6) DRRPS & 0.210 & -0.220 & 0.162 & 0.160 & -0.078 & 1.000 & \\
& 0.152 & 0.137 & 0.271 & 0.279 & 0.601 & & \\
(7) DFLT & -0.017 & 0.035 & 0.111 & 0.165 & -0.011 & $0.290^{* * *}$ & 1.000 \\
& 0.910 & 0.817 & 0.454 & 0.263 & 0.941 & 0.046 & \\
\hline
\end{tabular}

For correlation between population growth and other factors like annual rains, GDP per capita growth, DRRPS and DFLT is insignificant at all level of significance. While association between DRRPS and DFLT is .290 indicating a low but significant and positive relationship between them. In addition, to examine overall problem of high correlation, VIF test is applied and findings are presented under table 3. It is observed that for Mean VIF is 1.157 while individual VIF for all other explanatory variables is below 2, reflecting no problem for high 
correlation. Therefore, all explanatory variables can be considered for the further analysis of the study.

Table 3. Variance Inflation Factor

\begin{tabular}{lcl}
\hline & VIF & 1/VIF \\
\hline DRRPS & 1.258 & .795 \\
REC & 1.226 & .815 \\
POGR & 1.226 & .816 \\
DFLT & 1.143 & .875 \\
REFMM & 1.097 & .912 \\
GDPPCG & 1.094 & .914 \\
TEMP & 1.058 & .945 \\
MEAN VIF & 1.157 &. \\
\hline
\end{tabular}

Table four indicates the regression findings for the first half of data set during the time of 19701990 with annual observations for both tourism industry and key factors of climate change and economic growth. Through POGR, coefficient of .661 indicates an increasing and significant effect on tourism industry, meaning that more tourism receipts are possible with the growth of population in the economy. This effect is significantly positive at 1 percent chance of error with high t-value. Through renewable energy consumption, effect on tourism industry receipts is found to be negatively insignificant. Through level of temperature in the economy of Malaysia, impact on tourism receipt is found to be -.786 indicating its negative and significant influence at 1 percent level of significance. T-value for this relationship is 4.46 above cut point of 1.96. Droughts, floods, extreme temperatures have shown their insignificant influence on tourism industry in the region of Malaysia during 1970 to 1990 for the very first sub sample of time. Under this time period, overall explanatory power is .633 indicating an above moderate level of variation in tourism industry. While F-test indicates the significance of model fit with the value of 4.20 and prob. score of .034 , significant at 5 percent significant level.

Table five reflects the effect of key factors under the title of climate change and growth of GDP per capita in the economy of Malaysia during 2nd half of the data set of 1991 to 2017. It is observed that effect of population growth rate is -.297 and standard error is .065 , indicating negatively significant influence on receipt of tourism industry in recent time. Through renewable energy consumption, insignificant influence with the coefficient of -.012 is observed. For temperature similar insignificant influence is observed. However, factors like rain fall per millimeter on annual basis indicate its significantly positive influence on tourism industry. While effect through GDP per capita is found to be positively significant at 10 percent level of significant during the time of 1991 to 2017. While the factor of drought and disaster risk reduction score indicate their insignificant impact on tourism receipt in Malaysia. Value of robust R-square is 89.7 with the F-test of 22.512, significant at 5 percent level of significance.

Table 4. Linear regression (1970, 1990) 


\begin{tabular}{|c|c|c|c|c|c|}
\hline LGTR & Coef. & St.Err & t-value & p-value & Sig. \\
\hline POGR & 0.616 & 0.046 & 13.39 & 0.000 & $* * *$ \\
\hline REC & -0.005 & 0.003 & -1.69 & 0.114 & \\
\hline TEMP & -0.786 & 0.176 & -4.46 & 0.000 & $* * *$ \\
\hline REFMM & 0.000 & 0.000 & 0.78 & 0.452 & \\
\hline GDPPCG & 0.002 & 0.003 & 0.81 & 0.435 & \\
\hline DRRPS & 0.014 & 0.010 & 1.38 & 0.190 & \\
\hline DFLT & -0.006 & 0.005 & -1.08 & 0.299 & \\
\hline _cons & 9.568 & 0.227 & 42.20 & 0.000 & $* * *$ \\
\hline Mean dependent var & & 9.767 & SD dependent var & & 0.053 \\
\hline R-squared & & 0.633 & Number of obs & & 21.000 \\
\hline F-test & & 4.200 & Prob $>F$ & & 0.034 \\
\hline Akaike crit. (AIC) & & -70.080 & Bayesian crit. (BIC) & & -61.724 \\
\hline
\end{tabular}

Table 5. Linear regression $(1991,2017)$

\begin{tabular}{|c|c|c|c|c|c|}
\hline LGTR & Coef. & St.Err & t-value & p-value & Sig. \\
\hline POGR & -0.297 & 0.065 & -4.54 & 0.000 & $* * *$ \\
\hline REC & -0.012 & 0.028 & -0.44 & 0.665 & \\
\hline TEMP & -0.003 & 0.019 & -0.18 & 0.862 & \\
\hline REFMM & 0.587 & 0.125 & 4.69 & 0.000 & $* * *$ \\
\hline GDPPCG & 0.015 & 0.007 & 2.09 & 0.051 & $*$ \\
\hline DRRPS & -0.012 & 0.022 & -0.55 & 0.591 & \\
\hline DFLT & 0.003 & 0.008 & 0.35 & 0.730 & \\
\hline cons & 11.206 & 0.534 & 21.00 & 0.000 & $* * *$ \\
\hline Mean dependent var & 9.922 & & endent var & & 0.303 \\
\hline $\mathrm{R}$-squared & 0.897 & & of obs & & 26.000 \\
\hline F-test & 22.513 & & & & 0.000 \\
\hline Akaike crit. (AIC) & -32.571 & & n crit. (BIC) & & -22.506 \\
\hline
\end{tabular}

$* * * \mathrm{p}<0.01, * * \mathrm{p}<0.05, * \mathrm{p}<0.1$

Table six shows regression findings for the 2 nd measure of tourism industry as measured through international tourism expenditure in Malaysia. Effect of population growth on tourism expense is .810 , which is found to be insignificant under time duration of 1970 to 1990 . While effect of renewable energy consumption is significant and positive with the coefficient value of .167 and standard error of .033. In addition, effect of disaster risk reduction progress score is found to be significant and positive determinant of tourism expenditure, conducted by the Government during 1970 to 1990 . Explanatory power of the model as measured through Rsquare is .709 , significant at 5 percent confidence level with the significant value of F-test as well.

Table seven reflects the climate change and growth of GDP per capita in the economy of Malaysia during 2 nd half of the data set of 1991 to 2017 for tourism expense. It is observed that effect of population growth rate is -.950 and standard error is .375 , indicating negatively significant influence on overall expense of tourism industry in recent time. Through renewable energy consumption, insignificant influence with the coefficient of -.016 is observed. For temperature, similar insignificant influence is observed. However, factors like rain fall per millimeter on annual basis indicate its significantly positive influence on tourism industry. 
While effect through GDP per capita is found to be negatively insignificant at 10 percent level of significant during the time of 1991 to 2017. While the factor of drought and disaster risk reduction score indicate their insignificant impact on tourism receipt in Malaysia. Value of robust R-square is 74.9 percent with the F-test of 7.659 , significant at 5 percent level of significance.

Table 6. Linear regression 1970-1990

\begin{tabular}{|c|c|c|c|c|c|}
\hline ITEXP & Coef. & St.Err & t-value & p-value & Sig. \\
\hline POGR & 0.810 & 0.501 & 1.62 & 0.130 & \multirow{3}{*}{$* * *$} \\
\hline REC & 0.167 & 0.033 & 5.08 & 0.000 & \\
\hline TEMP & -0.009 & 0.061 & -0.15 & 0.880 & \\
\hline REFMM & 0.254 & 0.652 & -0.09 & 0.933 & \multirow{5}{*}{$* *$} \\
\hline GDPPCG & 0.009 & 0.033 & 0.28 & 0.783 & \\
\hline DRRPS & 0.248 & 0.111 & 2.24 & 0.043 & \\
\hline DFLT & -0.088 & 0.057 & -1.56 & 0.142 & \\
\hline _cons & -3.642 & 2.485 & -1.47 & 0.166 & \\
\hline Mean dependent var & 1.092 & \multicolumn{2}{|c|}{ SD dependent var } & \multicolumn{2}{|c|}{0.648} \\
\hline R-squared & 0.709 & \multicolumn{2}{|c|}{ Number of obs } & \multicolumn{2}{|c|}{21.000} \\
\hline F-test & 4.517 & \multicolumn{2}{|c|}{ Prob $>$ F } & \multicolumn{2}{|c|}{0.009} \\
\hline Akaike crit. (AIC) & 30.471 & \multicolumn{2}{|c|}{ Bayesian crit. (BIC) } & \multicolumn{2}{|c|}{38.828} \\
\hline
\end{tabular}

Table 7: Linear regression 1991-2017

\begin{tabular}{|c|c|c|c|c|c|}
\hline ITEXP & Coef. & St.Err & t-value & p-value & Sig. \\
\hline POGR & -0.950 & 0.375 & -2.53 & 0.021 & $* *$ \\
\hline REC & -0.016 & 0.163 & -0.10 & 0.925 & \\
\hline TEMP & -0.033 & 0.110 & -0.29 & 0.771 & \\
\hline REFMM & 0.524 & 0.04 & 9.703 & 0.000 & $* * *$ \\
\hline GDPPCG & -0.025 & 0.042 & -0.60 & 0.554 & \\
\hline DRRPS & -0.065 & 0.126 & -0.52 & 0.611 & \\
\hline DFLT & 0.060 & 0.045 & 1.33 & 0.200 & \\
\hline cons & 8.339 & 3.063 & 2.72 & 0.014 & $* *$ \\
\hline Mean dependent var & 3.912 & & ndent var & & 1.110 \\
\hline $\mathrm{R}$-squared & 0.749 & & of obs & & 26.000 \\
\hline F-test & 7.659 & & & & 0.000 \\
\hline Akaike crit. (AIC) & 58.296 & & crit. (BIC) & & 68.361 \\
\hline
\end{tabular}

Table 8 presents the effect of selected climate change indicator and GDP growth on log value of tourism receipt. It is found that increasing population growth in the economy, causing an up shift in the value of tourism receipt with the coefficient of .251 and standard error of .021. Meanwhile, $t$-value is 12.13 and p-value is 0.000 , significant at 1 percent level of significance. Through renewable energy consumption (REC), effect on LGTR is -0.016 with the standard error of .005 , significant at 1 percent. This effect shows the fact that renewable energy consumption as a significant source of climate change, causing an adverse influence on LGTR. Through GDP growth rate, effect on LGTR is .014 with the standard error .005 and t- 
value of 3.01. Overall explanatory power of the model is 84.5 with the F-test of 30.395, significant at 5 percent level of significance.

Table 8: Linear regression overall 1970-2017

\begin{tabular}{llcccc}
\hline LGTR & Coef. & St.Err & t-value & p-value & Sig. \\
\hline POGR & 0.251 & 0.021 & 12.13 & 0.000 & $* * *$ \\
REC & -0.016 & 0.005 & -3.07 & 0.004 & $* * *$ \\
TEMP & 0.254 & 0.910 & .270 & 0.989 & 0.210 \\
REFMM & 0.000 & 0.000 & 1.28 & 0.005 & $* * *$ \\
GDPPCG & 0.014 & 0.005 & 3.01 & 0.470 \\
DRRPS & -0.010 & 0.013 & -0.73 & 0.538 \\
DFLT & 0.0031 & 0.006 & 0.62 & 0.000 & $* * *$ \\
cons & 10.796 & 0.283 & 38.09 & 0.239 \\
\hline Mean dependent var & 9.853 & \multicolumn{3}{c}{ SD dependent var } & 47.000 \\
R-squared & 0.845 & \multicolumn{3}{c}{ Number of obs } & 0.000 \\
F-test & 30.395 & \multicolumn{3}{c}{ Bayesian crit. (BIC) } \\
Akaike crit. (AIC) & -73.814 & \multicolumn{5}{c}{-59.013} \\
\hline
\end{tabular}

$* * * \mathrm{p}<0.01, * * \mathrm{p}<0.05, * \mathrm{p}<0.1$

Table 9 presents the effect of selected climate change indicator and GDP growth on log value of tourism receipt. It is found that increasing population growth in the economy, causing an up shift in the value of tourism receipt with the coefficient of 1.892 and standard error of .198. Through renewable energy consumption (REC), effect on LGTR is 0.181 with the standard error of .050 significant at 1 percent. This effect shows the fact that renewable energy consumption as a significant source of climate change, causing a direct influence on LGTR. Through GDP growth rate, effect on LGTR is .014 with the standard error .005 and t-value of 3.01. Overall explanatory power of the model is 71.7 with the F-test of 14.114 , significant at 5 percent level of significance.

Table 9: Linear regression overall 1970-2017

\begin{tabular}{|c|c|c|c|c|c|}
\hline ITEXP & Coef. & St.Err & t-value & p-value & Sig. \\
\hline POGR & 1.892 & 0.198 & 9.57 & 0.000 & $* * *$ \\
\hline REC & 0.181 & 0.050 & 3.60 & 0.001 & $* * *$ \\
\hline TEMP & 0.058 & 0.100 & 0.58 & 0.567 & \\
\hline REFMM & -0.002 & 0.004 & -0.63 & 0.534 & \\
\hline GDPPCG & -0.002 & 0.043 & -0.04 & 0.967 & \\
\hline DRRPS & 0.198 & 0.128 & 1.55 & 0.130 & \\
\hline DFLT & -0.010 & 0.053 & -0.20 & 0.846 & \\
\hline cons & 7.753 & 2.711 & 2.86 & 0.007 & $* * *$ \\
\hline Mean dependent var & & 2.652 & SD dependent var & & 1.691 \\
\hline R-squared & & 0.717 & Number of obs & & 47.000 \\
\hline F-test & & 14.114 & Prob $>$ F & & 0.000 \\
\hline Akaike crit. (AIC) & & 138.448 & Bayesian crit. (BIC) & & 153.249 \\
\hline
\end{tabular}




\section{Conclusion}

This study has examined the effect of climate change and growth of GDP with population on tourism industry of Malaysia. Findings through regression analysis have been divided into three major categories. First time duration is examined during the period of 1970 to 1990 , second is through 1991 to 2017 and third is examined for overall time duration of 1970 to 2017. It is found that for the first proxy of tourism receipt in the country during the time duration of 1970 to 1990 , key indicators from the climate change are temperature level, and population growth rate for overall receipt for tourism industry. In addition, during the time of 1991 to 2017, key determinants of tourism receipt are population growth rate, rain fall, and GDP per capita growth have their significant influence on overall tourism industry. For tourism expense, key determinants during first half of data set is renewable energy consumption and disaster risk reduction programs score in the country. While the second half is population growth rate and rain fall. As per the findings for overall sample period, key determinants of tourism receipt are population growth rate, renewable energy consumption, and GDP per capita growth rate. For 2 nd measure of tourism measured as overall expense in tourism industry, key determinants are population growth rate and renewable energy consumption. These findings are providing a significant guideline to various policy makers, country officials and those who are responsible to deal with increase issues of climate change in Malaysia. Additionally, theoretical and practical significance of the study can be viewed in a way that it has added reasonable empirical contribution in existing literature. Empirical facts explained that reasonable attention is required to deal with the significant relationship between climate change and tourism industry. Practical implications covers not only the context of Malaysia but can be expanded to other economies in ASEAN region. However, study is limited towards the consideration of specific indicators under the title of climate change. Future research can be conducted while adding more factors of climate change in targeted regions.

\section{References}

[1] A. Liu and G. Wall, "Planning tourism employment: a developing country perspective," Tour. Manag., vol. 27, no. 1, pp. 159-170, 2006.

[2] S. Majeed, C. Lu, M. Majeed, and M. Shahid, "Health Resorts and Multi-Textured Perceptions of International Health Tourists," Sustainability, vol. 10, no. 4, p. 1063, 2018.

[3] L. I. U. De-qian, "Several Discriminations in Rural Tourism, Agriculture Tourism and Folklore Tourism [J]," Tour. Trib., vol. 3, 2006.

[4] M. Fabinyi, "Dive tourism, fishing and marine protected areas in the Calamianes Islands, Philippines," Mar. Policy, vol. 32, no. 6, pp. 898-904, 2008.

[5] S. G. Britton, "The political economy of tourism in the Third World," Ann. Tour. Res., vol. 9, no. 3, pp. 331-358, 1982.

[6] W. R. Eadington and M. Redman, "Economics and tourism," Ann. Tour. Res., vol. 18, no. 1, pp. 41-56, 1991

[7] B. Amelung, S. Nicholls, and D. Viner, "Implications of global climate change for tourism flows and seasonality," J. Travel Res., vol. 45, no. 3, pp. 285-296, 2007.

[8] W. N. Adger, S. Huq, K. Brown, D. Conway, and M. Hulme, "Adaptation to climate change in the developing world," Prog. Dev. Stud., vol. 3, no. 3, pp. 179-195, 2003.

[9] C. B. Field, V. Barros, T. F. Stocker, and Q. Dahe, Managing the risks of extreme events and disasters to advance climate change adaptation: special report of the intergovernmental panel 
on climate change. Cambridge University Press, 2012.

[10] J. L. Eugenio-Martin and J. A. Campos-Soria, "Climate in the region of origin and destination choice in outbound tourism demand," Tour. Manag., vol. 31, no. 6, pp. 744-753, 2010.

[11] H. Middelkoop et al., "Impact of climate change on hydrological regimes and water resources management in the Rhine basin," Clim. Change, vol. 49, no. 1-2, pp. 105-128, 2001.

[12] G. Wall and C. Badke, "Tourism and climate change: an international perspective," J. Sustain. Tour., vol. 2, no. 4, pp. 193-203, 1994.

[13] B. Seetanah and S. Fauzel, "Investigating the impact of climate change on the tourism sector: evidence from a sample of island economies," Tour. Rev., vol. 74, no. 2, pp. 194-203, 2019.

[14] P. J. Burton and S. G. Cumming, "Potential effects of climatic change on some western Canadian forests, based on phenological enhancements to a patch model of forest succession," Water. Air. Soil Pollut., vol. 82, no. 1-2, pp. 401-414, 1995.

[15] U. Koenig and B. Abegg, "Impacts of climate change on winter tourism in the Swiss Alps," $J$. Sustain. Tour., vol. 5, no. 1, pp. 46-58, 1997.

[16] W. Lise and R. S. J. Tol, "Impact of climate on tourist demand," Clim. Change, vol. 55, no. 4, pp. 429-449, 2002.

[17] S. Sookram, "The impact of climate change on the tourism sector in selected Caribbean countries," Caribb. Dev. Rep., vol. 2, no. 30, pp. 204-225, 2009.

[18] R. Culpan, "International tourism model for developing economies," Ann. Tour. Res., vol. 14, no. 4, pp. 541-552, 1987.

[19] H. Latimer, "Developing-island economies—-tourism v agriculture," Tour. Manag., vol. 6, no. 1, pp. 32-42, 1985.

[20] B. Seetanah, "Assessing the dynamic economic impact of tourism for island economies," Ann. Tour. Res., vol. 38, no. 1, pp. 291-308, 2011.

[21] M. Tretheway and D. Mak, "Emerging tourism markets: Ageing and developing economies," $J$. air Transp. Manag., vol. 12, no. 1, pp. 21-27, 2006.

[22] R. Durbarry and B. Seetanah, "The impact of long haul destinations on carbon emissions: The case of Mauritius," J. Hosp. Mark. Manag., vol. 24, no. 4, pp. 401-410, 2015.

[23] C. J. Lemieux, T. J. Beechey, D. J. Scott, and P. A. Gray, Protected areas and climate change in Canada: challenges and opportunities for adaptation. Canadian Council on Ecological Areas, 2000. 